\title{
ANALISIS FAKTOR-FAKTOR YANG MEMPENGARUHI INDEKS PRESTASI KUMULATIF (IPK) LULUSAN S-1 MATEMATIKA FMIPA UNAND DENGAN MENGGUNAKAN METODE CHAID
}

\author{
DONI PUTRA, IZZATI RAHMI HG, YUDIANTRI ASDI \\ Program Studi S1 Matematika, \\ Fakultas Matematika dan Ilmu Pengetahuan Alam, Universitas Andalas, \\ Kampus Unand Limau Manis, Padang, Indonesia \\ email : doniputra2610@gmail.com, izzatirahmihg@sci.unand.ac.id, \\ yudiantriasdi@sci.unand.ac.id
}

Diterima 16 Juni 2020 Direvisi 22 Juni 2020 Dipublikasikan 13 Juli 2020

\begin{abstract}
Abstrak. Prestasi belajar merupakan hasil pencapaian yang maksimal menurut kemampuan seseorang pada waktu tertentu pada sesuatu yang dipelajari, dikerjakan, dimengerti, dan diterapkan. Pengukuran akan capaian prestasi belajar seseorang dalam perguruan tinggi ditetapkan dalam bentuk Indeks Prestasi Semester (IPS) dengan skala $0-4$ tiap semesternya yang nantinya akan dikalkulasikan menjadi Indeks Prestasi $\mathrm{Ku}-$ mulatif (IPK) di akhir masa perkuliahan. Berdasarkan hasil Data Wisuda Jurusan Matematika tahun 2016 - 2018, lulusan banyak terdapat pada selang $3 \leq \mathrm{IPK}<3.5$. Di samping itu, lulusan dengan IPK selang $3.5 \leq$ IPK $\leq 4$ masih sedikit sekali jika dibandingkan dengan lulusan yang mempunyai IPK selang $3 \leq$ IPK $<3.5$. Untuk mengetahui faktor-faktor yang berpengaruh terhadap Indeks Prestasi Kumulatif (IPK) Lulusan S-1 Jurusan Matematika FMIPA Unand dilakukan suatu penelitian dengan metode klasifikasi berstruktur pohon menggunakan metode CHAID (Chi-Square Automatic Interaction Detection). Objek penelitian ini adalah Lulusan S-1 Jurusan Matematika FMIPA Unand. Berdasarkan analisis CHAID yang telah dilakukan, terdapat empat faktor yang paling berpengaruh terhadap IPK lulusan yaitu perpustakaan, kesempatan untuk berinteraksi dengan dosen di luar jadwal kuliah, ketuntasan materi perkuliahan, dan kondisi umum belajar.
\end{abstract}

Kata Kunci: Prestasi belajar, Selang IPK, Uji Khi-Kuadrat $\left(\chi^{2}\right)$, Metode Berstruktur Pohon, Metode CHAID

\section{Pendahuluan}

Berdasarkan hasil Data Wisuda Jurusan Matematika tahun 2016 - 2018 yang terdiri dari 199 lulusan, IPK lulusan pada selang $2.5 \leq$ IPK $<3$ terdapat sebanyak $6.03 \%$, pada selang $3 \leq \mathrm{IPK}<3.5$ sebanyak $85.43 \%$, dan pada selang $3.5 \leq \mathrm{IPK}$

*penulis korespondensi 
$\leq 4$ sebanyak $8.54 \%$. Dari data wisuda tersebut, disimpulkan lulusan banyak terdapat pada selang $3 \leq$ IPK $<3.5$. Di samping itu, lulusan dengan IPK selang 3.5 $\leq \mathrm{IPK} \leq 4$ masih sedikit sekali jika dibandingkan dengan lulusan yang mempunyai IPK selang $3 \leq$ IPK $<3.5$. Hal ini dapat menjadi bahan evaluasi bagi Jurusan Matematika untuk dapat menyusun program untuk meningkatkan mutu layanan akademik dalam menunjang keberhasilan studi mahasiswa.

Berdasarkan hasil Data Wisuda tersebut, dilakukan suatu penelitian untuk mengetahui faktor-faktor yang mempengaruhi indeks prestasi kumulatif (IPK) lulusan Jurusan Matematika Unand. Penelitian dilakukan dengan menggunakan salah satu metode dalam teknik klasifikasi yaitu metode CHAID (Chi-Square Automatic Interaction Detection) dengan menjadikan IPK sebagai variabel dependen $\mathrm{Y}$ dan faktor yang diduga mempengaruhi IPK lulusan sebagai variabel independen $\mathrm{X}$.

\section{Landasan Teori}

\subsection{Prestasi Belajar}

Prestasi belajar merupakan hasil pencapaian yang maksimal menurut kemampuan seseorang pada waktu tertentu pada sesuatu yang dipelajari, dikerjakan, dimengerti, dan diterapkan. Prestasi belajar merupakan hasil dari proses belajar mengajar yang didapat dengan baik oleh seorang tersebut baik dalam pendidikan atau bidang keilmuan tertentu. Seseorang tersebut memperoleh prestasi belajar dari hasil yang telah dicapai dari proses belajar selama beberapa waktu yang dibutuhkan. Dalam proses pendidikan prestasi diartikan sebagai hasil dari proses belajar mengajar berupa penguasaan, perubahan tingkah laku, atau perubahan emosional yang dapat diukur dengan pengujian tertentu [1].

\subsection{Metode Berstruktur Pohon}

Metode berstruktur pohon merupakan salah satu metode alternatif yang dapat digunakan untuk menjelaskan hubungan antara variabel dependen dengan variabel independen. Metode ini dapat dibedakan menjadi dua bagian yaitu metode pohon klasifikasi yang digunakan bila variabel dependen adalah peubah kategorik (nominal atau ordinal) dan metode pohon regresi yang digunakan bila variabel dependen adalah peubah kontinu. Terdapat beberapa metode yang dapat digunakan dalam analisis data berstruktur pohon, diantaranya metode CART, CHAID dan QUEST, untuk pohon klasifikasi, dan metode AID, CART dan GUIDE untuk pohon regresi $[2]$.

\subsection{Metode CHAID}

Metode CHAID (Chi-Square Automatic Interaction Detection) adalah salah satu metode dalam teknik klasifikasi yang digunakan untuk kondisi masing-masing variabel dependen dan variabel independen merupakan variabel kategorik (nominal dan ordinal). Jika terdapat variabel kontinu, maka variabel tersebut dapat digunakan dengan melakukan transformasi menjadi variabel berskala ordinal sebelum dianalisis 
dengan metode CHAID [3]. Metode CHAID menggunakan Uji Khi-Kuadrat dalam proses penggabungan kategori dan pemilihan variabel penyekat untuk setiap simpul yang terbentuk. Misalkan terdapat dua variabel kategorik, variabel-1 dengan $r$ kategori dan variabel-2 dengan $c$ kategori akan diuji kebebasannya. Data dapat disajikan dalam tabel tabulasi silang seperti Tabel 1.

Tabel 1. Tabel Tabulasi Silang Uji Khi-Kuadrat

\begin{tabular}{|c|c|c|c|c|c|}
\hline \multirow{2}{*}{ Kategori Variabel-1 } & \multicolumn{4}{|c|}{ Kategori Variabel-2 } & \multirow{2}{*}{ Total } \\
\cline { 2 - 6 } & 1 & 2 & $\cdots$ & $c$ & \\
\hline 1 & $O_{11}$ & $O_{12}$ & $\cdots$ & $O_{1 c}$ & $n_{1 .}$ \\
\hline 2 & $O_{21}$ & $O_{22}$ & $\cdots$ & $O_{2 c}$ & $n_{2 .}$ \\
\hline$\vdots$ & $\vdots$ & $\vdots$ & $\vdots$ & $\vdots$ & $\vdots$ \\
\hline$r$ & $O_{r 1}$ & $O_{r 2}$ & $\cdots$ & $O_{r c}$ & $n_{r .}$ \\
\hline Total & $n_{.1}$ & $n_{.2}$ & $\cdots$ & $n_{. c}$ & $n$ \\
\hline
\end{tabular}

Banyaknya objek pengamatan yang teramati pada kategori ke- $i$ dari variabel1 dan kategori ke- $j$ dari variabel-2 ditempatkan pada perpotongan baris ke- $i$ dan kolom ke- $j$. Nilai objek pengamatan yang teramati disebut frekuensi sel pengamatan (observed cell frequency) dan dilambangkan dengan $O_{i j}$. Sementara itu frekuensi sel yang diharapkan (expected cell frequency) dilambangkan dengan $E_{i j}$ yang dapat dihitung dengan rumus :

$$
E_{i j}=\frac{n_{i} n_{j}}{n} .
$$

Hipotesis yang digunakan pada pengujian Khi-Kuadrat adalah :

$H_{0}$ : kedua variabel saling bebas,

$H_{1}$ : kedua variabel tidak saling bebas.

Statistik Uji $\chi^{2}$ yang digunakan adalah [4]:

$$
\chi^{2}=\sum_{i=1}^{r} \sum_{j=1}^{c} \frac{\left(O_{i j}-E_{i j}\right)^{2}}{E_{i j}} .
$$

Penolakan hipotesis nol $\left(H_{0}\right)$ yang menyatakan bahwa kedua variabel saling bebas pada taraf nyata $\alpha$ diputuskan ketika nilai statistik uji $\chi^{2}$ hasil perhitungan $>$ $\chi_{\alpha,((r-1)(c-1))}^{2}$ atau $p$-value $<\alpha$.

Algoritma CHAID adalah sebagai berikut [3]:

(1) Untuk masing-masing variabel independen, dibuat tabulasi silang antara kategori-kategori variabel independen dengan kategori-kategori variabel dependen.

(2) Dari setiap tabulasi yang diperoleh, disusun semua subtabel berukuran $2 \mathrm{x} d$ dengan tabulasi silang yang mungkin. $d$ adalah banyaknya kategori variabel dependen. Dicari nilai $\chi^{2}$ semua subtabel tersebut. Jika terdapat 
subtabel yang memiliki nilai $\chi^{2}$ terkecil dengan $\chi^{2}<\chi_{\alpha((1)(d-1))}^{2}$, maka kedua kategori variabel independen tersebut digabung menjadi satu kategori gabungan.

(3) Pada setiap kategori gabungan yang terdiri atas tiga atau lebih kategori asal, dicari pembagian biner yang paling signifikan. Dari pembagian ini dicari $\chi^{2}$ terbesar. Jika $\chi^{2}$ terbesar $>\chi_{\alpha((r-1)(c-1))}^{2}$ maka pembagian biner berlaku. Kembali ke tahap 2 .

(4) Setelah diperoleh penggabungan optimal untuk setiap variabel independen, dihitung nilai $p$-value yang terkecil dari masing-masing subtabel tersebut. Jika $p$-value terkecil $<\alpha$, maka variabel independen pada $p$-value tersebut adalah variabel independen yang paling signifikan terhadap variabel dependen.

(5) Jika pada tahap 4 diperoleh variabel yang pengaruhnya paling signifikan, kembali ke tahap 1 untuk setiap data hasil pemisahan.

Pengurangan tabel tabulasi silang pada algoritma CHAID $c$ kategori dari variabel independen menjadi $r$ kategori $(r<c)$, maka $p$-value dari Khi-Kuadrat yang baru dikalikan dengan Pengganda Bonferroni berikut sesuai dengan tipe variabel $[3]:$

(1) Variabel Nominal Variabel Nominal adalah variabel yang kategorinya murni nominal, rumusnya yaitu:

$$
B=\sum_{i=0}^{r-1}(-1)^{i} \frac{(r-i)^{c}}{i !(r-i) !}
$$

(2) Variabel Monotonik

Variabel monotonik adalah variabel yang kategorinya terletak pada skala ordinal, rumusnya yaitu:

$$
B=\left(\begin{array}{l}
c-1 \\
r-1
\end{array}\right)
$$

(3) Variabel Float

Variabel Float biasanya terletak pada skala ordinal dengan terdapat satu kategori yang posisinya tidak diketahui dalam skala ordinal tersebut, rumusnya yaitu:

$$
B=\left(\begin{array}{l}
c-2 \\
r-2
\end{array}\right)+\left(\begin{array}{l}
c-2 \\
r-1
\end{array}\right)
$$

\section{Pembahasan}

Analisis dilakukan terhadap 137 data pengamatan yang terdiri dari 22 orang lulusan dengan $2.5 \leq \mathrm{IPK}<3$ (16\%), 96 orang lulusan dengan $3 \leq \mathrm{IPK}<3.5$ (70\%), dan 19 orang lulusan dengan $3.5 \leq \mathrm{IPK} \leq 4$ (14\%). Jadi untuk variabel dependen indeks prestasi kumulatif (IPK) lulusan didominasi oleh kategori $3 \leq$ IPK $<3.5$ dengan persentase yang cukup signifikan jika dibandingkan dengan dua kategori yang 
lainnya. Analisis dilakukan terhadap satu variabel dependen yaitu indeks prestasi kumulatif (IPK) lulusan dengan tujuh variabel independen yaitu modul belajar, laboratorium, perpustakaan, kesempatan untuk berinteraksi dengan dosen di luar jadwal kuliah, kondisi umum belajar mengajar, ketuntasan materi perkuliahan, dan kurikulum/silabus perkuliahan.

\subsection{Analisis Pohon Klasifikasi CHAID}

Hasil diagram pohon CHAID disajikan pada Gambar 1. Pada gambar tersebut tampak bahwa perpustakaan merupakan faktor yang paling berpengaruh terhadap IPK lulusan sehingga faktor perpustakaan dipilih sebagai variabel yang menyekat simpul akar menjadi dua kelompok yaitu penilaian perpustakaan kurang dan penilaian perpustakaan sangat baik, baik, dan cukup. Faktor lain yang juga mempengaruhi IPK lulusan yaitu kesempatan untuk berinteraksi dengan dosen di luar jadwal kuliah, ketuntasan materi perkuliahan, dan kondisi umum belajar.

Karakteristik IPK lulusan berdasarkan diagram CHAID dapat dilihat pada Tabel 2 di bawah ini.

Tabel 2. Karakteristik dan Dugaan IPK Lulusan pada Setiap Kelompok

\begin{tabular}{|c|c|c|c|}
\hline $\begin{array}{l}\text { Kelompok } \\
\text { ke- }\end{array}$ & $\begin{array}{l}\text { Simpul } \\
\text { akhir }\end{array}$ & Karakteristik & $\begin{array}{l}\text { Dugaan } \\
\text { IPK }\end{array}$ \\
\hline 1 & 1 & $\begin{array}{c}\text { Lulusan dengan penilaian perpustakaan } \\
\text { kurang }\end{array}$ & $3.5 \leq \mathrm{IPK} \leq 4$ \\
\hline 2 & 5 & $\begin{array}{l}\text { Lulusan dengan penilaian perpustakaan } \\
\text { sangat baik, baik, dan cukup } \\
\text { Interaksi dengan dosen cukup dan kurang } \\
\text { Kondisi umum belajar cukup dan kurang }\end{array}$ & $2.5 \leq \mathrm{IPK}<3$ \\
\hline 3 & 6 & $\begin{array}{l}\text { Lulusan dengan penilaian perpustakaan } \\
\text { sangat baik, baik, dan cukup } \\
\text { Interaksi dengan dosen cukup dan kurang } \\
\text { Kondisi umum belajar sangat baik dan baik }\end{array}$ & $3 \leq \mathrm{IPK}<3.5$ \\
\hline 4 & 7 & $\begin{array}{c}\text { Lulusan dengan penilaian perpustakaan } \\
\text { sangat baik, baik, dan cukup } \\
\text { Interaksi dengan dosen sangat baik dan baik } \\
\text { Ketuntasan materi perkuliahan } \\
\text { cukup dan kurang }\end{array}$ & $3 \leq \mathrm{IPK}<3.5$ \\
\hline 5 & 8 & $\begin{array}{c}\text { Lulusan dengan penilaian perpustakaan } \\
\text { sangat baik, baik, dan cukup } \\
\text { Interaksi dengan dosen sangat baik dan baik } \\
\text { Ketuntasan materi perkuliahan } \\
\text { sangat baik dan baik }\end{array}$ & $3 \leq \mathrm{IPK}<3.5$ \\
\hline
\end{tabular}

Berdasarkan Tabel 2 tampak bahwa karakteristik dan dugaan IPK lulusan terdiri atas lima kelompok dengan dugaan IPK yang berbeda-beda. Dari lima kelom- 


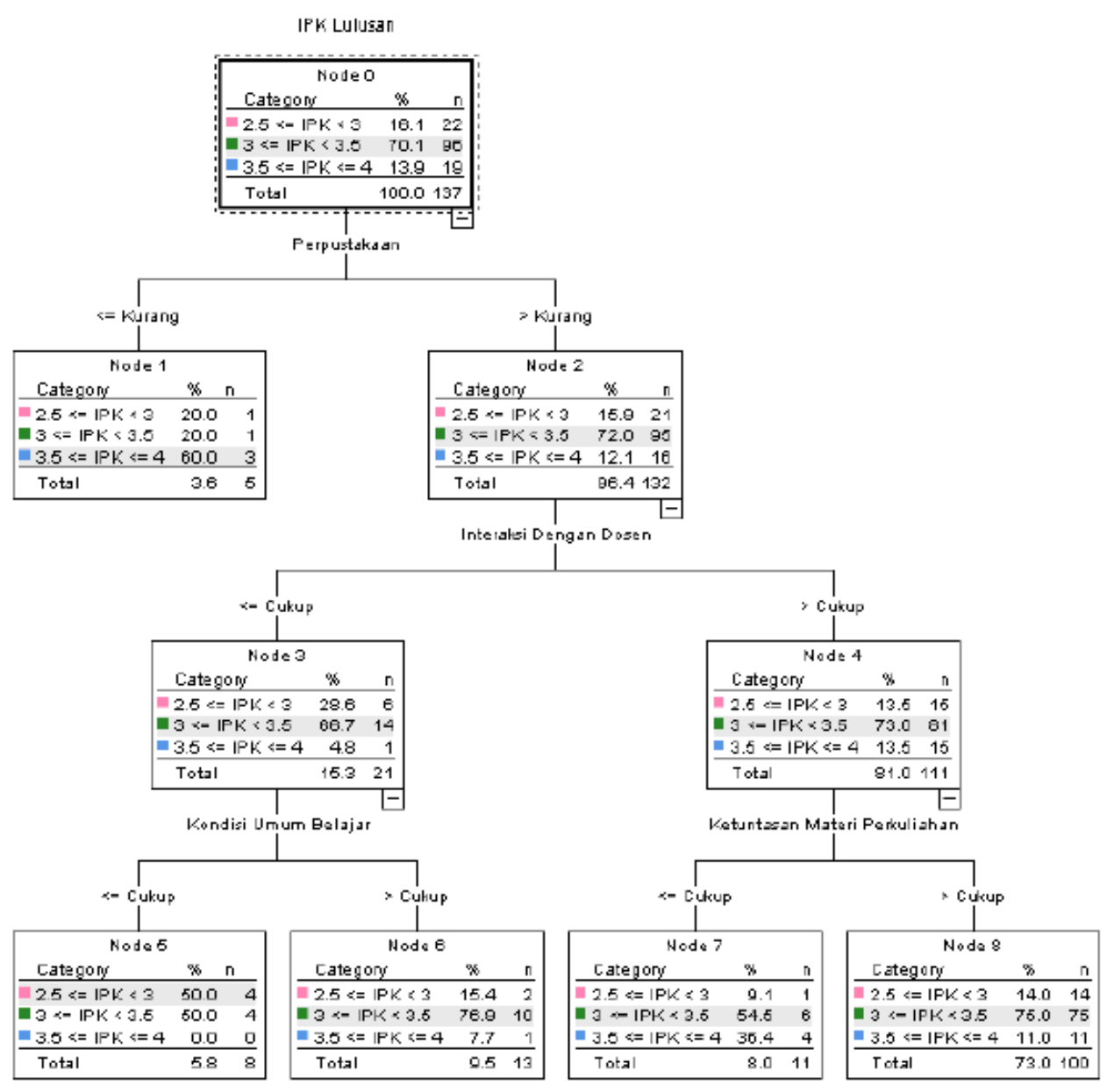

Gambar 1. Diagram Pohon Analisis CHAID untuk IPK

pok yang terbentuk, tiga diantaranya diduga adalah lulusan dengan IPK selang 3 $\leq \mathrm{IPK}<3.5$, dan sisanya lulusan dengan IPK selang $2.5 \leq \mathrm{IPK}<3$ dan $3.5 \leq$ IPK $\leq 4$. Dari tabel tersebut ada satu hal yang menjadi perhatian, dimana lulusan dengan IPK selang $3.5 \leq$ IPK $\leq 4$ justru menilai perpustakaan dengan penilaian kurang. Hal tersebut terjadi mungkin karena perpustakaan masih kurang memenuhi apa yang mereka inginkan. Sebagai contoh, karena keterbatasan buku yang ada di perpustakaan, mereka sering tidak menemukan buku atau jurnal yang mereka perlukan, padahal bagi mereka buku atau jurnal tersebut sangat penting. Hal ini mengakibatkan mereka meberikan penilaian yang kurang baik terhadap perpustakaan di Jurusan Matematika.

Berdasarkan Tabel 3, dapat dilihat bahwa berdasarkan sebaran data lulusan untuk semua kategori variabel dependen IPK banyak terdapat pada kelompok-5, 
Tabel 3. Sebaran IPK pada Setiap Kelompok yang terbentuk

\begin{tabular}{|c|c|c|c|c|c|c|}
\hline \multirow{2}{*}{ Kelompok } & \multicolumn{2}{|c|}{$2.5 \leq \mathrm{IPK}<3$} & \multicolumn{2}{c|}{$3 \leq \mathrm{IPK}<3.5$} & \multicolumn{2}{c|}{$3.5 \leq \mathrm{IPK} \leq 4$} \\
\cline { 2 - 7 } & $\mathrm{n}$ & $\%$ & $\mathrm{n}$ & $\%$ & $\mathrm{n}$ & $\%$ \\
\hline 1 & 1 & $4.54 \%$ & 1 & $1.04 \%$ & 3 & $15.79 \%$ \\
\hline 2 & 4 & $18.18 \%$ & 4 & $4.17 \%$ & 0 & $0 \%$ \\
\hline 3 & 2 & $9.09 \%$ & 10 & $10.42 \%$ & 1 & $5.26 \%$ \\
\hline 4 & 1 & $4.54 \%$ & 6 & $6.25 \%$ & 4 & $21.06 \%$ \\
\hline 5 & 14 & $63.65 \%$ & 75 & $78.12 \%$ & 11 & $57.89 \%$ \\
\hline Total & $\mathbf{2 2}$ & $\mathbf{1 0 0 \%}$ & $\mathbf{9 6}$ & $\mathbf{1 0 0 \%}$ & $\mathbf{1 9}$ & $\mathbf{1 0 0 \%}$ \\
\hline
\end{tabular}

yaitu lulusan dengan penilaian perpustakaan sangat baik, baik, dan cukup, interaksi dengan dosen sangat baik dan baik, dan ketuntasan materi perkuliahan sangat baik dan baik. Artinya sebagian besar lulusan sudah memberikan penilaian positif terhadap perpustakaan, interaksi dosen di luar jam kuliah dan ketuntasan materi perkuliahan.

\section{Kesimpulan}

Dalam penelitian ini, dilakukan analisis terhadap faktor-faktor yang mempengaruhi indeks prestasi kumulatif (IPK) lulusan S-1 Matematika FMIPA Unand. Faktorfaktor yang diteliti adalah faktor eksternal yang berkaitan aspek belajar mengajar dan sarana prasarana di kampus dengan menggunakan metode CHAID. Dari tujuh faktor yang dianalisis, terdapat empat faktor yang paling berpengaruh terhadap IPK lulusan yaitu perpustakaan, kesempatan untuk berinteraksi dengan dosen di luar jadwal kuliah, ketuntasan materi perkuliahan, dan kondisi umum belajar. Metode CHAID memprediksi indeks prestasi kumulatif (IPK) dengan ketepatan klasifikasi sebesar $71,5 \%$.

Terdapat dua selang IPK lulusan dengan kasus yang berbeda yang patut diperhatikan. Kasus pertama adalah lulusan dengan penilaian perpustakaan sangat baik, baik, dan cukup, interaksi dengan dosen cukup dan kurang, dan kondisi umum belajar cukup dan kurang dengan IPK yang terdapat pada selang $2.5 \leq$ IPK $<3$. Lulusan dengan IPK yang terdapat pada selang $2.5 \leq \mathrm{IPK}<3$ masih cukup banyak jumlahnya.

Kasus selanjutnya, lulusan dengan IPK yang terdapat pada selang $3.5 \leq \mathrm{IPK} \leq$ 4 masih sedikit sekali lulusan yang lulus pada selang tersebut. Lulusan dengan IPK yang terdapat pada selang $3.5 \leq \mathrm{IPK} \leq 4$ banyak yang memberikan penilaian kurang terhadap perpustakaan. Dari dua kasus tersebut diharapkan bisa dijadikan pedoman bagi Jurusan Matematika dalam upayanya meningkatkan kualitas pelayanan jurusan maupun fasilitas yang tersedia.

\section{Daftar Pustaka}

[1] Abdullah, A. Prestasi Belajar. http://Spesialis_torch.com, diakses pada Kamis, 19 September 2019. Published : 2008. 
[2] Lewis, R. J. An Introduction to Classification and Regression Tree (CART) Analysis. Department of Emergency Medicine, Harbor-UCLA Medical Center, Torrance, California. Published : 2000

[3] Kass, G.V,. An Exploratory Technique for Investigating Large Quantities of Categorical Data. App. Statistic. 29(2): 119 - 127 Published : 1980

[4] Sunyoto, Danang. Uji Khi-Kuadrat dan Regresi untuk Penelitian. Graha Ilmu, Yogyakarta. Published : 2010. 